Ind. Health, 1972, 10, 11.

\title{
DIFFERENT RESPONSES OF DELTA-AMINOLEVULINIC ACID DEHYDRASE ACTIVITY TO SOME HEAVY METALS IN VIVO
}

\author{
Osamu WADA, Tetsu ONO, Ruriko MARU and Kohei TOYOKAWA \\ Department of Hygiene and Preventive Medicine, Faculty of Medicine, \\ University of Tokyo, Hongo, Bunkyo-ku, Tokyo
}

(Received May 12, 1972)

\begin{abstract}
Responses of delta-aminolevulinic acid (ALA) dehydrase activity in erythrocytes to cadmium, mercury and lead ions were investigated in vitro and in vivo.

In vitro all of three metals inhibited the purified enzyme activity at the concentration of $10^{-4} \mathrm{M}$, indicating that the enzyme belongs to the sulfhydryl enzymes.

On the other hand, the decrease of the enzyme activity below $40 \%$ of the control level was observed only in lead-treated mice, and in cadmium- or mercury-treated mice the transient decrease in the enzyme activity up to $40 \%$ of the control level in the initial stage was followed by the increase in the enzyme activity more than the control level in the later stage.

It is concluded that both the decrease of the ALA dehydrase activity betow $40 \%$ of the control level and the increase in urinary ALA excretion are specific parameters for lead exposure.
\end{abstract}

The essential biological effects of heavy metals have been attributed to inactivation of sulfhydryl ( $\mathrm{SH})$ groups of the enzymes by the metals ${ }^{1}$.

Delta-aminolevulinic acid (ALA) dehydrase which catalyses the synthesis of porphobilinogen (PBG) from two molecules of ALA is largely contained in erythrocytes and is demonstrated to contain sulfhydryl ( $\mathrm{SH})$ groups in its active site ${ }^{2)}$.

It has been generally agreed that the increased urinary excretion of ALA observed among lead workers ensues from the decreased activity of ALA dehydrase in erythrocytes ${ }^{3,4)}$. Furthermore, strong correlations are often found between the decreased activity of this enzyme and the concentration of lead in blood ${ }^{5)}$. This is the reason why the activity of ALA dehydrase in erythrocytes has been widely utilysed for the evaluation of lead exposure. However, the possession of essential SH groups by this enzyme and the strong affinity of heavy metals other than lead for SH groups seem to throw some doubt upon the specificity of this parameter for lead exposure.

The purpose of this investigation is to study the effect of lead, cadmium and mercury ions on the activity of ALA dehydrase in vivo as well as in vitro.

As for mercury a statistically significant correlation was recently found be- 


\section{O. WADA, T. ONO, R. MARU AND K. TOYOKAWA}

tween the urinary level of mercury and the value of the decreased activity of ALA dehydrase in the study of the mercury workers, though the decrease in the enzyme activity was slight as compared with that observed among the lead workers ${ }^{6}$.

\section{Materials AND Methods}

Experiment 1, studies in vitro

Purification of ALA dehydrase

ALA dehydrase was partially purified from $200 \mathrm{ml}$ of heparinized blood obtained from healthy volunteers according to the method of Calissano ${ }^{7)}$. The enzyme was finally purified 165 fold in its activity per protein weight.

\section{Preparation of metal sulotions}

Lead acetate, cadmium chloride or mercuric chloride was dissolved into $0.01 \mathrm{M}$ Tris-acetate buffer at $\mathrm{pH} 6.8$ to desirable concentrations. The $\mathrm{pH}$ of the solutions were adjusted to 6.8 with appropriate reagents.

\section{Determination of ALA dehydrase activity}

ALA dehydrase activity was determined by a slightly modified method of Wada et $a l^{8}$. Incubation was carried out in a mixture containing $0.1 \mathrm{ml}$ of the purified enzyme solution ( $0.18 \mathrm{mg}$ protein), $0.2 \mathrm{ml}$ of $0.1 \mathrm{M}$ Tris-acetate buffer at $\mathrm{pH} 6.8,0.1$ $\mathrm{ml}$ of $0.05 \mathrm{M}$ ALA solution and $0.1 \mathrm{ml}$ of the metal solution under air at $37^{\circ} \mathrm{C}$ for one hour. Blank tubes were identical except that they contained $0.1 \mathrm{ml}$ of water in place of ALA solution. The reaction was terminated by the addition of $1 \mathrm{ml}$ of $7 \%$ trichloroacetic acid. PBG in the aliquot was determined by addition of modified Ehrlich's reagent.

\section{Experiment 2, studies in vivo}

Preparation of animals

Male mice of DD strain weighing $20 \pm 2 \mathrm{~g}$ were devided into four groups according to four hinds of treatment. $0.2 \mathrm{ml}$ of each of solutions containing respectively $12.5 \mathrm{mg}$ of $\mathrm{CdCl}_{2}, 10.3 \mathrm{mg}$ of $\mathrm{HgCl}_{2}$ or $14.1 \mathrm{mg}$ of $\mathrm{Pb}\left(\mathrm{CH}_{3} \mathrm{COO}\right)_{2} \cdot 3 \mathrm{H}_{2} \mathrm{O}$ per $50 \mathrm{ml}$ of physiological saline was injected subcutaneously every day. These doses were calculated in order that $150 \mu \mathrm{g}$ of metal per $\mathrm{kg}$ body weight were administered to a mouse a day. To control groups only the same volume of physiological saline was injected. Four mice of each groups were sacrificed on 0 , 2nd, 4th, 7th, 12th, 15th and 20th day, and ALA dehydrase activity was determined.

\section{Determination of $A L A$ dehydrase activity ${ }^{8)}$}

Heparinized blood was obtained from axillar vein of the mice. After measuring the hematcrit, the erythrocytes were lysed by rapid freezing and thawing. Incubation was carried out in a mixture containing $0.2 \mathrm{ml}$ of lysed erythrocytes, $0.1 \mathrm{ml}$ of $0.1 \mathrm{M}$ phosphate buffer at $\mathrm{pH} 6.8$ and $0.1 \mathrm{ml}$ of $0.01 \mathrm{M}$ ALA solution under air at $37^{\circ} \mathrm{C}$ for $30 \mathrm{~min}$. The following procedure was the same as that described above. 


\section{ALA DEHYDRASE AND HEAVY METALS}

\section{RESULTS}

\section{Experiment 1, Studies in vitro}

Table 1 shows the inhibitory effects of lead, cadmium and mercury ions on the activity of the purified ALA dehydrase in vitro. No difference was observed among their inhibitory effects on the enzyme activity. As can be seen, all metals completely inhibited the activity at the concentration of $10^{-4} \mathrm{M}$.

Table 1. Effects of $\mathrm{Pb}, \mathrm{Cd}$ and $\mathrm{Hg}$ ions on the activity of purified ALA dehydrase in vitro.

\begin{tabular}{l|crcccc}
\hline \multirow{2}{*}{ Added metals } & \multicolumn{5}{|c}{ Activity of ALA dehydrase } \\
\cline { 2 - 6 } & $0 \mathrm{M}$ & $10^{-6} \mathrm{M}$ & $\begin{array}{c}\text { Concentration of metal } \\
10^{-6} \mathrm{M}\end{array}$ & $10^{-4} \mathrm{M}$ & $10^{-3} \mathrm{M}$ & $10^{-2} \mathrm{M}$ \\
\hline $\mathrm{Pb}\left(\mathrm{CH}_{3} \mathrm{COO}\right)_{2}$ & $100 \pm 4.2$ & $98.2 \pm 5.6$ & $86.3 \pm 6.8$ & 0 & 0 & 0 \\
$\mathrm{CdCl}_{2}$ & & $101.2 \pm 5.8$ & $96.5 \pm 5.2$ & $5.2 \pm 0.8$ & 0 & 0 \\
$\mathrm{HgCl}_{2}$ & & $99.8 \pm 4.6$ & $92.3 \pm 6.6$ & 0 & 0 & 0 \\
\hline
\end{tabular}

Activities of ALA dehydrase were expressed as percentage of control value

Figures express mean $\pm \mathrm{S}$. D. of three experiments.

\section{Experiment 2, Studies in vivo}

As shown in Fig. 1, subcutaneous administration of lead decreased ALA dehydrase activity of erythrocytes below $40 \%$ of the control level already on the 2nd day, and the decrease in enzyme activity continued to the level of 0 to $5 \%$ of the

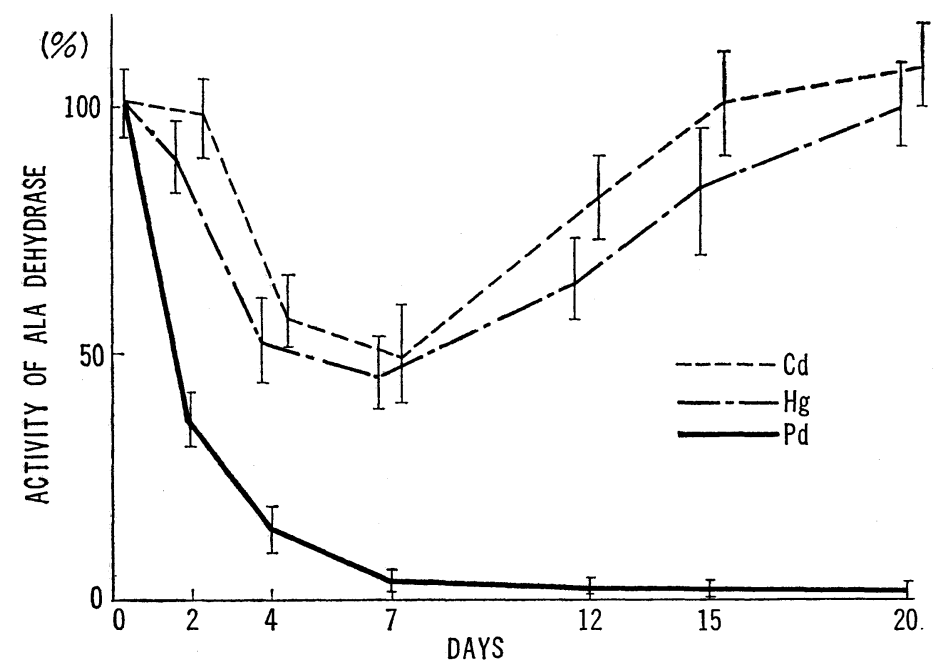

Fig. 1. Changes of erythrocyte ALA dehydrase activity during the treatment of mice with subcutaneous injections of $\mathrm{Pb}, \mathrm{Cd}$, and $\mathrm{Hg}$ compounds. Activities of ALA dehydrase are expressed as percentage of control values, and bars represent mean $\pm S$. D. of four animals. 


\section{O. WADA, T. ONO, R. MARU AND K. TOYOKAWA}

control as long as lead was administered.

On the other hand, though ALA dehydrase activity of erythrocytes obtained from cadmium or mercury injected group showed a transient decrease on the 4th and 7 th day, the restration of the enzyme activity was observed on the 12th day and, furthermore, the enzyme activity continued to recover to a higher level than the control on the 15th and 20th day in spite of the continued administration of the metals.

The decrease in the enzyme activity below $40 \%$ of the control was observed only in the lead injected group.

\section{Discussion}

The present study showed that the activity of ALA dehydrase in erythrocytes of mice treated with lead was markedly decreased already in the initial stage of the treatment. This is in accordance with the previously reported observation in the studies on workers exposed to lead ${ }^{4}$.

Although, as shown in Table 1 , in vitro cadmium and mercury inhibited the activity of purified ALA dehydrase in the same degree as lead, showing that the enzyme has SH groups at its essential sites, the former two metals showed the different effects on the enzyme activity in vivo as compared with those of lead, that is, the transient inhibition in the early stage and the activation in the later stage of the treatment.

The increase in the activity of cadmium or mercury treated groups was observed when the activity decreased to $40 \%$ of the control level. Considering the previous observations ${ }^{8)}$ that the disturbance of $\mathrm{PBG}$ synthesis followed by the increased excretion of ALA in urine was found only when ALA dehydrase activity was decreased below $40 \%$ of the control level, a kind of feedback or rebound mechanism might be taking place in the animals exposed to cadmium or mercury. Furthermore, these results are well in accordance with the observations ${ }^{6,9)}$ that no increase of urinary ALA has been found among workers exposed to cadmium or mercury.

On the other hand, it is reported that a considerable amount of cadmium or mercury is incorporated into red blood cells when absorbed in the blood ${ }^{10)}$. Taking into the consideration this fact, it is suggested that both cadmium and mercury in red blood celle are probably at the conditiion hardly to approach ALA dehydrase, and that only lead has a chemical structure to be able to get near ALA dehydrase in vivo.

These results indicate that the decrease in ALA dehydrase activity below $40 \%$ of the control level and the increase in urinary ALA excretion are good parameters for lead exposure. 


\section{ALA DEHYDRASE AND HEAVY METALS}

\section{REFERENCES}

1) Vallee, B. L. and Wacker, W.E.C. (1970). Metalloproteins, Acad. Press, New York and London.

2) Gibson, K. D., Neuberger, A. and Scott, J. J. (1955). Biochem. J., 61, 618.

3) Haeger, B. (1957). Scand. J. Clin. Lab. Invest., 9, 211.

4) Nakao, K., Wada, O. and Yano, Y. (1968). Clin. Chim. Acta, 19, 319.

5) Wada, O. and Ohi, G. (1972). Rev. Environ. Health, 1, 75.

6) Wada, O., Toyokawa, K., Suzuki, T., Suzuki, S., Yano, Y. and Nakao, K. (1969). Arch. Environ. Health, 19, 485.

7) Calissano, J. (1966). Biochem. J., 101, 550.

8) Wada, O., Yano, Y., Kurashina, S., Ono, T. and Toyokawa, K. (1970). Asian Med. J., 13, 581.

9) Goldwater, L. J. and Joselow, M. M. (1967). Arch. Environ. Health, 15, 327.

10) Suzuki, T., Miyama, T. and Katsunuma, H. (1970). Ind. Health, 8, 39. 